\title{
Os primórdios do movimento sufragista no Brasil: o feminismo "pátrio" de Leolinda Figueiredo Daltro
}

The early days of women's suffrage movement in Brazil: Leolinda Figueiredo Daltro's "patrio" feminism

Los antecedentes del movimiento sufragista en Brasil: el feminismo "patrio" de Leolinda Figueiredo Daltro

Mônica Karawejczyk

Resumo: Esse artigo pretende elucidar a participação de Leolinda Figueiredo Daltro, na luta em prol do sufrágio feminino no Brasil, de modo a destacar a sua importância para a primeira fase do movimento sufragista. A atuação de Daltro, nas primeiras décadas do século $\mathrm{XX}$, fez com que a questão da emancipação política feminina voltasse a ser um tema debatido pela sociedade da época. Assim o objetivo central desse texto é conhecer uma das personagens/protagonistas que fez parte da luta em prol do sufrágio feminino no Brasil.

Palavras-chave: Leolinda Figueiredo Daltro. Movimento sufragista. Primeira República.

Abstract: The aim of this article is to elucidate the participation of Leolinda Figueiredo Daltro in the struggle for women's suffrage in Brazil, in order to highlight her importance to the first phase of the Suffrage Movement. Thanks to Daltro's central action in the first decades of the twentieth century, the issue of women's political emancipation returned to be a debated topic in the society at that time. Therefore the central aim of this text is to understand one of the main characters/actors who took part in the struggle for women's suffrage in Brazil.

Keywords: Leolinda Figueiredo Daltro. Suffrage Movement. First Republic.

a Doutora, Bacharel e Licenciada em História pela UFRGS. Mestre pela PUCRS. A pesquisa para esse artigo contou com o apoio do CNPq. Atualmente sou pesquisadora-residente na Fundação Biblioteca Nacional, com bolsa de pesquisa da instituição. <karawejczyk@gmail.com>. 
Resumen: Se pretende aclarar en ese texto, la participación de Leolinda Figueiredo Daltro, en la lucha a favor del sufragio femenino en Brasil, de manera a poner en relieve su importancia en la primera fase del movimiento sufragista. La actuación de Figueiredo Daltro, en las primeras décadas del siglo XX, hizo con que la cuestión política de la emancipación femenina, volviera a presentarse como un tema de debate para la sociedad de la época. Así, el objetivo central del texto es conocer uno de los personajes, que fue protagonista en la lucha a favor del sufragio femenino en Brasil.

Palabras clave: Leolinda Figueiredo Daltro. Movimiento sufragista. Primera República.

Num epitáfio do cemitério São João Batista, na cidade do Rio de Janeiro, está escrito:

\author{
Leolinda Figueiredo Daltro \\ Mamãe - nosso ourinho \\ $14 / 07 / 1859$ \\ 04/05/1935 \\ Precursora do verdadeiro feminismo pátrio \\ Propugnadora da nobilitação dos humildes \\ e humanização dos selvícolas.
}

Tais palavras gravadas na pedra expressam mais que a dor da perda, exprimem o orgulho de uma família, que fez questão de deixar para a posteridade um resumo sobre o que foi a vida dessa mulher: mãe estimada, feminista, preocupada com os humildes e com os indígenas.

Ao nos depararmos com essa inscrição tumular, em pleno século $\mathrm{XXI}$, ficamos intrigados e questionamos: quem foi essa mulher? O que fez para despertar esse tipo de admiração na sua família? E, afinal, o que querem eles dizer com "precursora do verdadeiro feminismo pátrio?" Quem foi, afinal, Leolinda Figueiredo Daltro?

$\mathrm{Na}$ procura por respostas para essas perguntas, acabamos nos deparando com os primeiros passos de um movimento organizado feminino no Brasil - movimento liderado por ninguém menos que Leolinda. Esta organização tomou a forma peculiar de um partido político, o Partido Republicano Feminino (PRF). Assim, ao procurar elucidar uma inscrição tumular, acabamos nos deparando com uma das pioneiras do movimento sufragista brasileiro e é esta história, pela 
sua singularidade e importância, que se quer aqui apresentar. Para alcançar esse objetivo, começamos por fazer uma busca sistematizada na bibliografia referente ao sufrágio feminino no Brasil, na qual se constatou o quão pouco se sabe sobre Leolinda Daltro e muito menos sobre o seu papel de pioneira do movimento sufragista, tema ainda pouco conhecido e pesquisado. O nome mais lembrado e exaltado quando se fala na luta em prol do voto feminino no Brasil é o de Bertha Lutz, mundialmente conhecida pela sua atuação à frente da Federação Brasileira pelo Progresso Feminino (FBPF), associação feminina fundada em 1922.

Assim, este artigo foi elaborado com a intenção de preencher tal lacuna e está estruturado de forma a elucidar o que foi gravado na lápide dessa mulher após a sua morte. A fonte principal de consulta sobre a participação de Daltro no movimento sufragista foram os periódicos, publicados na capital federal, da época em questão. Esclareço que os textos jornalísticos foram compreendidos como uma representação que deixou entrever a sociedade da época retratada e as atitudes ali introjetadas.

Ao resgatar a história dessa mulher também se pode compreender alguns aspectos referentes à história dos gêneros, masculino e feminino, nos anos iniciais da República no Brasil, no sentido de que, em qualquer grupo social e período histórico, as definições do papel de cada um dos gêneros resultam de padrões e de embates culturais, e não de determinações biológicas, tal como apresentado por Joan Scott (2008). Este também é um momento oportuno para uma reflexão sobre os primórdios da luta feminista no Brasil, uma vez que, no ano de 2012, comemoramos 80 anos da conquista do voto feminino, com a peculiaridade de, neste mesmo ano, termos uma mulher ocupando o cargo mais elevado do Executivo do país.

\section{Antes de ser feminista}

Leolinda nasceu em 1859 na Bahia, casou-se cedo, como de costume na época, e teve dois filhos. Logo se separou do marido, o que teria sido uma motivação para estudar para ser professora e, assim, ajudar nas economias domésticas (Rocha, 2002, p.48). Aos 24 anos, estava casada novamente e migrou, com o novo marido, para a Capital Federal, em "busca de melhores condições de vida" (Abreu, 2007, p. 16). No Rio de Janeiro, conseguiu um cargo para ministrar aulas e também começou a se interessar pela proposta positivista na área da educação - proposta 
que dava destaque a uma educação laica (Rocha, 2002; Abreu, 2007) ${ }^{1}$. Seu nome passou a ser conhecido no Brasil quando

ganhou notoriedade [...] pela defesa intransigente dos direitos dos índios. Apaixonada pela ideia de incorporar os índios brasileiros à sociedade por meio da alfabetização sem conotações religiosas, usou de todos os artifícios ao seu alcance, inclusive o contato com pessoas influentes para iniciar no ano de 1896 o ambicioso projeto de percorrer o interior do Brasil promovendo a alfabetização de tribos indígenas (Melo; Marques, 2000, p. 72).

Nessa época, a proposta de Daltro era polêmica e inovadora para a época, pois "o debate público em torno da questão pendia ora em favor da catequização acompanhada da completa aculturação das tribos, ora em favor da sumária eliminação das populações indígenas remanescentes no Brasil" (Schumaher, 2000, p. 318). Segundo apresenta Elaine Rocha (2002), Leolinda mantinha e explorava uma grande rede de contatos junto ao governo, antes e após a queda da Monarquia, dentre os quais cita os nomes de Quintino Bocaiuva, José do Patrocínio, Hermes da Fonseca e Pinheiro Machado. Tais contatos teriam lhe facilitado a intermediação entre a imprensa e a sociedade para arrecadar fundos para o seu projeto de alfabetização indígena. Ela percorreu durante mais de quatro anos o interior de Goiás para colocar em prática esse projeto, retornando ao Rio de Janeiro no final de 1900. Mesmo esse projeto não tendo sido bem sucedido, Daltro ainda se dedicaria à causa indígena até 1911. Essa parte da sua vida foi resumida por seus filhos no seu epitáfio com as seguintes palavras: Propugnadora da nobilitação dos humildes e humanização dos selvícolas.

Para Maria Emília Vieira de Abreu (2007, p. 18), "sua proposta política ia pelo viés da educação e essa era a sua prática como professora, como indigenista e como feminista. Reforçava a importância civilizadora da mulher e mostrava preocupação com a sobrevivência das mesmas".

\footnotetext{
${ }^{1}$ Com o novo marido Leolinda teve mais três filhos. Segundo apontam as pesquisas de Elaine Rocha (2002) logo após sua vinda para o Rio de Janeiro, Leolinda deve ter se separado ou ficado viúva. Seu nome também aparece grifado como Deolinda em muitos artigos, provavelmente devido ao trocadilho feito por Lima Barreto, que em suas crônicas e artigos sempre se referia a ela trocando-lhe o nome: ora tratava-a por D. Florinda, como em Numa e a Ninfa, ora como D. Deolinda. Agradeço à prof ${ }^{\mathrm{a}} \mathrm{Dr}^{\mathrm{a}}$ Elaine Pereira Rocha, da University of West Indies - Cave Hill, pelo envio de sua tese, que foi fundamental para compreender a história de Leolinda Daltro bem como à prof ${ }^{\mathrm{a}} \mathrm{Dr}^{\mathrm{a}}$ Teresa Novaes Marques, da Universidade Federal de Brasília, pelo envio do seu artigo sobre o PRF. Todas as citações da tese de Elaine Rocha foram feitas a partir do volume enviado diretamente pela autora, o que pode ocasionar certas discrepâncias em relação ao exemplar que se encontra na biblioteca da USP.
} 
Por conta de sua ousadia, recebeu vários epítetos e a imprensa da época assim a descreveu: "santa, anjo, excêntrica, monomaníaca, visionária, heroína, louca de hospício, doce mãe, aproveitadora, herege e anticristo foram alguns dos títulos que ela recebeu de admiradores e desafetos" (Rocha, 2002, p. 4). Leolinda Daltro é também descrita como sendo uma mulher que

com seu temperamento intempestivo, teve que lidar com as duras críticas da opinião pública, de políticos e de colegas de magistério, que relutavam em aceitar que uma mulher deixasse seu lar e filhos para aventurar-se pelos sertões em companhia de índios e que ousasse retornar e disputar espaço político com os homens (Rocha, 2002, p. 4).

Ela esteve em evidência na imprensa por quase 15 anos, ou seja, "o tempo que durou o debate sobre a política indigenista que o Estado Brasileiro deveria adotar. Posteriormente, seu nome ressurgiria vez por outra nas páginas dos noticiários, em defesa de uma outra causa: o feminismo" (Rocha, 2002, p. 4).

O objetivo primordial da professora Daltro no começo do século $\mathrm{XX}$ foi a causa indigenista. A sua tentativa infrutífera de obter um cargo oficial junto ao governo para atuar na área de educação indígena parece ser o que contribuiu de forma decisiva para a conscientização de que a sua condição de mulher é que estava sendo um empecilho para atingir seus objetivos, afinal foram as

dificuldades encontradas [...] para atingir o seu principal objetivo, a nomeação oficial como catequista leiga ou como Diretora de Índios, [que] deram-lhe a certeza de que não conseguiria realizar seus intentos sem engajar-se na luta pelos direitos políticos das mulheres, já que era a sua condição sexual o maior empecilho à realização de seus anseios (Rocha, 2002, p. 268).

Tal constatação também pode ser exemplificada por outros dois fatos acontecidos na vida de Daltro. O primeiro deles ocorrido em 1902, logo após retornar da viagem aos sertões de Goiás, quando então

procurou o IHB [Instituto Histórico Brasileiro] propondo a criação de uma associação civil de amparo aos indígenas. No dia 26 de setembro de 1902, o assunto foi levado à pauta de reunião dos sócios do Instituto. Impedida de participar, pessoalmente, da reunião 
sob a alegação de que era mulher, Leolinda viveu por certo não a primeira, mas uma marcante demonstração de que os limites para a participação feminina em assuntos de domínio público estavam colocados rigidamente (Marques, 2004, p. 161).

O outro fato ocorreu poucos anos depois, em 1909, quando foi impedida de apresentar um trabalho com suas propostas para a política indigenista oficial no Primeiro Congresso Brasileiro de Geografia. O motivo alegado para vetar a sua participação foi novamente a sua condição sexual. De modo que parecem ter sido a sua condição de mulher e a maneira como ela era tratada perante a sociedade os principais entraves para a realização de suas metas e ideais. Essa teria sido a mola propulsora que teria levado Daltro a refletir sobre a situação de inferioridade da mulher e a buscar mudá-la através de alguma ação. Interessante apontar que a ação proposta por ela fosse a busca pela participação ativa das mulheres no mundo político, iniciando a sua luta pelo reconhecimento do sufrágio feminino.

\section{Pelo direito do voto}

Durante muito tempo o direito de votar foi entendido como um privilégio de poucos, e estes poucos sendo exclusivamente do gênero masculino, brancos e possuidores de bens. A historiografia costuma vincular o termo universal ao tipo de sufrágio que se estabeleceu em 1848, na França, quando caiu a exigência monetária para ser eleitor e difundiu no mundo a concepção dos homens como politicamente iguais, através de um novo princípio eleitoral o do sufrágio direto sem qualquer limitação de censo. Essa cidadania que surgiu com a abolição do sufrágio censitário fez com que emergisse uma visibilidade sem precedentes até então entre a separação política entre homens e mulheres.

Somente a partir dessa época se começou a pensar a situação política das mulheres como uma exclusão; até então, elas haviam sido situadas, de preferência, em uma exterioridade, fruto de uma não inclusão e não tanto de uma rejeição por causa de seu sexo. Falando de modo específico das mulheres, a imagem mais recorrente da época é que elas deveriam se manter a margem da comunidade política, na segurança de seus lares e sob o governo dos homens (Stransell, 2010). Tal como apontam Joan Scott (2002) e Michelle Perrot (2005), a cidadania política feminina viu-se relegada a um patamar difícil de ser contestado, uma vez que o conceito se viu atrelado a uma diferenciação sexual e a exclusão foi 
baseada exclusivamente no quesito "sexo". Segundo Anne Verjus (2005, p.428), este é o "início do sexismo como fundamento da exterioridade política das mulheres". Joan Scott também compartilha esta ideia ao declarar:

Quando se legitimava a exclusão com base na diferença biológica entre o homem e a mulher, estabelecia-se que a 'diferença sexual' não apenas era um fato natural, mas também uma justificativa ontológica para um tratamento diferenciado no campo político e social (Scott, 2002, p. 26).

A partir dessa explícita não inclusão das mulheres é que começou a surgir no mundo ocidental um movimento feminino em busca do reconhecimento de sua cidadania política e pela igualdade de direitos. A questão do sufrágio feminino passou, aos poucos, a ser a agenda principal das vindicações femininas deixando de ser considerado apenas como o símbolo da desigualdade entre homens e mulheres, para ser elevado à prioridade do movimento, principalmente partir de 1890 (Pugh, 2000, p. 87). O voto deixou de ser considerado como meramente simbólico e passou a ser visto como a chave para grandes mudanças e as mulheres que almejavam participar do mundo político passaram a focar seus esforços para influenciar as decisões do Parlamento e sensibilizar seus participantes em reformar a lei em benefício das mulheres. Segundo Maria Zina Abreu,

as sufragistas argumentavam que as vidas das mulheres não melhorariam até que os políticos tivessem de prestar contas a um eleitorado feminino. Acreditavam que as muitas desigualdades legais, econômicas e educacionais com que se confrontavam jamais seriam corrigidas, enquanto não tivessem o direito de voto. A luta pelo direito de voto era, portanto, um meio para atingir um fim (Abreu, 2002, p. 460).

É bom lembrar que o Brasil é um dos países pioneiros tanto na concessão do voto para as mulheres na América Latina quanto no debate sobre ele no Parlamento. Algumas peculiaridades quanto a essa questão podem ser aqui destacadas: as discussões sobre a possibilidade de se estender o voto para as brasileiras já ocorreram no final do século XIX, durante a feitura da carta constitucional republicana, em um momento em que o voto para as mulheres não era concedido em lugar algum do mundo. Esse é um ponto que nos diferencia de outras nações, tal como 
os EUA, por exemplo, onde o tema não tinha sido agendado para debate no Congresso Nacional até a década de 1910 (Abreu, 2002; Rowbotham, 1997). Outro ponto a ser destacado foi a própria redação final do artigo 70 na Constituição que, ao declarar "São eleitores os cidadãos maiores de 21 anos, que se alistarem na forma da lei", permitiu que contestações fossem feitas pelas mulheres que queriam participar do mundo político, pois o referido artigo não deixou explícita a exclusividade masculina na participação eleitoral.

Tais aspectos são relevantes na medida em que nos diferenciam do que aconteceu em outros países, como nos EUA e na Inglaterra, por exemplo, que deixaram clara a exclusão das mulheres da política, ao empregar o termo "masculino" nas suas legislações, nesses foi a explícita exclusão feminina que passou a denotar com clareza os limites naturais impostos à participação das mulheres na política. Entretanto não foi isso o que aconteceu no Brasil, onde os constituintes do século XIX abriram um precedente que, mais tarde, seria explorado pelos partidários do sufrágio feminino.

\section{Leolinda Daltro e o Partido Republicano Feminino}

O primeiro ato conhecido de Leolinda Daltro nas vias políticas foi através da congregação de algumas mulheres em apoio à candidatura de Hermes da Fonseca à presidência do Brasil, no ano de 1909, com a fundação da Junta Feminil pró-Hermes. Mariana Coelho (2002, p. 152) descreve esse grupo como uma "associação política de cuja descrição se depreende ser o ponto de partida para a ação do feminismo no Brasil, pois foi a primeira fundada com intuitos de trabalhar pela emancipação do sexo feminino brasileiro". Em 1910, Leolinda rebatizou essa associação feminina com o nome de Partido Republicano Feminino (PRF). Segundo Céli Pinto (2003, p. 18), essa forma de nomear tal associação feminina já "merece atenção especial pela ruptura que representou [...] pelo fato de ser um partido político composto por pessoas que não tinham direitos políticos, cuja atuação, portanto, teria de ocorrer fora da ordem estabelecida". Seria isso que os seus filhos queriam dizer ao mandar lapidar as palavras "precursora do verdadeiro feminismo pátrio" na sua lápide? O que nos leva a questionar o que motivou uma professora a fundar um partido político, em uma época em que efetivamente a mulher não tinha voz na política?

O programa do PRF, publicado no Diário Oficial em 17 de dezembro de 1910, apregoava que pretendia "congregar a mulher brasileira na 
capital federal e em todos os Estados do Brasil, promovendo a cooperação entre as mulheres na defesa das causas relativas ao progresso pátrio". O quarto artigo do estatuto do partido definia que ele deveria: "Pugnar para que sejam consideradas extensivas às mulheres as disposições constitucionais da República dos Estados Unidos do Brasil, desse modo incorporando-a na sociedade brasileira" (Diario Oficial, 1910, p.47). Dentre as referidas "disposições constitucionais" elencadas, a mais perseguida pelas militantes foi o reconhecimento das mulheres como cidadãs plenas e passíveis de participar das pugnas eleitorais. De forma que não parece ser demais considerar que as ações do partido teriam sido as responsáveis por recolocar o tema do sufrágio feminino de volta à pauta da imprensa brasileira. Um diferencial na proposta do PRF era ser composto exclusivamente por mulheres, pois pelo seu estatuto, estava vedada a participação masculina ${ }^{2}$. O partido também contava, desde antes da sua fundação oficial, com bandeira, gorros e distintivos para a sua identificação (O Paiz, 21 out. 1910, p. 2) $)^{3}$.

Apesar do interdito imposto no programa do PRF a participação masculina nos seus quadros de sócios, Daltro procurava o apoio dos políticos da época para a sua causa, se aproveitando da aproximação de figuras políticas masculinas de destaque para dar visibilidade aos atos do partido em suas manifestações públicas, como atestam várias matérias encontradas nos jornais do período.

Leolinda tinha múltiplas lutas e interesses, mas a partir da primeira década do século XX passou a se dedicar cada vez mais em prol da emancipação feminina. Em junho de 1910 também lançou, no Rio de Janeiro, um jornal intitulado A Política, cuja proposta era tão ampla quanto uma "plataforma de candidato a cargo federal" e, segundo Rocha (2002, p. 295-296), incluía desde a questão da catequese laica e do direito das mulheres à educação e ao voto, até propostas para promover o saneamento moral da sociedade, além de servir, mais tarde, para fazer propaganda do PRF. A própria Daltro, em entrevista concedida em 1934 para o jornal carioca $A$ Noite, faz um relato sobre o surgimento da Junta, relacionando-o à fundação do PRF. Nessa entrevista Leolinda é apresentada aos leitores do jornal com as seguintes palavras: "por volta de 1910, pela primeira vez, no Brasil, surgiu uma mulher desfraldando a bandeira das reivindicações feministas, afrontando o indiferentismo

\footnotetext{
${ }^{2}$ A fundação do partido se deu no dia 23 de dezembro de 1910 e o seu registro oficial, em 18 de agosto de 1911.

${ }^{3}$ Todos os jornais citados ao longo desse texto foram consultados de forma on-line na hemeroteca digital brasileira da Fundação Biblioteca Nacional, no endereço eletrônico: $<$ http://memoria.bn/br> .
} 
reinante" (A Noite, 03 ago. 1934, p. 1). O jornalista aponta que "a cruzada nova provocou comentários irreverentes e escandalizou a mentalidade conservadora da época" pois, Daltro e suas associadas, tinham por hábito comparecer a todas as solenidades cívicas na capital federal, com o intuito de dar visibilidade a sua causa. Teresa Marques aponta que "a forma de mobilização adotada por Leolinda e suas colaboradas pairava o espectro das radicais suffragettes inglesas, que puseram seus corpos a serviço da causa do sufrágio feminino, invadindo as ruas da Inglaterra" (Marques, 2004, p. 163) ${ }^{4}$. Quando questionada sobre como o PRF surgiu, Leolinda assim se pronunciou: "Fui uma grande amiga de Pinheiro Machado. Aquele homem enérgico, ríspido e franco, recebiame sempre em seu palacete com encantadora fidalguia. Estava ele no auge de seu prestígio político, mas eu nunca lhe solicitei favor nenhum" (A Noite, 03 ago. 1934, p. 2). A professora passou então a relatar, para o jornalista, de que forma teve a ideia de organizar um grupo de amigas para formar a Junta Feminil pró-Hermes:

Um dia, em conversa com o general Pinheiro Machado, disse-lhe que ia dissolver a Junta. O chefe Gaúcho depois de refletir um pouco ponderou: - Por que não a transforma num partido político? Pode até dar-lhe o nome de Partido Republicano Feminino. E assim foi. Continuamos a trabalhar sob a nova denominação. Promovíamos festas cívicas, comemorávamos as datas nacionais e fazíamos conferências, no sentido de educar politicamente a mulher, dandolhe uma noção nova de seu valor e fazendo-a ver que dia viria em que ela seria chamada a participar dos negócios públicos ( $A$ Noite, 03 ago. 1934 , p. 2$)^{5}$.

Segundo as palavras de Leolinda, ela não pregou "diretamente a conquista de postos de representação"; tanto ela quanto suas

\footnotetext{
${ }^{4}$ Suffragette foi um termo cunhado, pela imprensa do Reino Unido no início do século XX, para diferenciar o grupo liderado por Emmeline Pankhurst - o Women's Social and Political Union (WSPU), mais combativo e militante em prol do sufrágio feminino - do grupo do National Society for Women's Suffrage (NSWS). O movimento pró-voto feminino tanto no Reino Unido quanto nos EUA teve duas fases distintas: a primeira, nas suas campanhas, deu prioridade à moderação, sempre observando a lei e a ordem, apostando em redigir petições e mandar cartas para a imprensa na expectativa de sensibilizar a opinião pública para o seu lado, estratégia que não se mostrou muito eficaz. A segunda fase, mais conhecida, foi agressiva e militante, apostando em ações para dar visibilidade para a sua causa, tais como colocar fogo em caixas de correio, quebrar vidraças, interromper discursos dos parlamentares, participar de passeatas, entre outras coisas. Estas ficaram conhecidas como suffragettes, para se diferenciarem do grupo mais pacífico, das sufragistas.

${ }^{5}$ A referida ideia da criação de um partido político feminino por um político gaúcho não pôde ser comprovada até o momento, mas não pode ser descartada a hipótese de ter feito parte de uma posterior estratégia aplicada pela própria Leolinda em uma tentativa de dar mais legitimidade ao seu projeto para concorrer a um cargo no legislativo.
} 
companheiras, apesar de não terem “ambições pessoais" nesse sentindo, queriam, "antes de tudo, dar à mulher, um lugar melhor na sociedade, como elemento de progresso, libertando-a tanto quanto possível, da escravidão e da situação de inferioridade em que vivia" ( $A$ Noite, 03 ago. 1934, p. 2).

Pouco se sabe sobre as táticas de pressão utilizadas pelo PRF nos seus anos iniciais, mas o certo é que, em 1913, os periódicos brasileiros deram ampla publicidade ao movimento das suffragettes, quase sempre acentuando que este não era um exemplo a ser seguido pelas brasileiras. Eram publicadas manchetes nos jornais da capital federal com advertências como: "As suffragettes precipitam os seus meios de ação", seguida pela admoestação "Vejam o que se passa na Inglaterra e tratem de evitá-lo" (A Noite, 14 jun. 1913, capa). O jornal O Paiz (RJ), por exemplo, divulgou no ano de 1913, em notas quase diárias, as atividades das "sufragistas militantes" dando ênfase aos incêndios, às quebras de vidraças e aos ataques aos políticos. Esse periódico acabou creditando a elas praticamente todos os atos violentos e atentados contra a ordem pública e a propriedade privada que aconteceram em Londres e arredores, mesmo sem provas. Outro periódico, alertava aos seus leitores que "as sufragistas não são para brincadeiras - as mulhereshomens" e salientava:

as terríveis sufragistas têm praticado e continuam a praticar desatinos de que muito homem não seria capaz. Já não se limitam as fervorosas propagandistas a simples quebras de vitrines, mas assaltam e queimam edifícios, ameaçam como há poucos dias, a catedral de São Paulo, cometem atos de furioso vandalismo (A Noite, 27 maio 1913, p.4).

O impacto dessas notícias não deve ser subestimado e sua repercussão negativa sobre a opinião pública deve ser levada em conta, ainda mais pelo fato de que Daltro passou a ser nomeada, pela imprensa, como a Miss Pankhurst brasileira, sendo identificada com o sufragismo mais militante.

\section{Uma suffragette nos trópicos}

A constante vinculação de Daltro à figura da líder suffragette inglesa, Emmeline Pankhurst, talvez seja uma explicação para que, em junho de 1914, a imprensa carioca noticie o aparecimento de uma 
"nova agremiação política - o Partido Republicano Feminista". Destacamos o final de uma matéria em que se pode ler: "e por aí vai a entusiasta iniciadora do advento sufragista entre nós, transportando para cá, as ideias de miss Pankhurst, depois de havê-las, porém, fumigado na estufa do seu extremado nativismo" ( $A$ Época, 03 jun. 1914, capa). O jornal $O$ Paiz, dando outra versão do mesmo episódio, publica que:

está fundado o Partido Republicano Feminino, que absolutamente não é uma agremiação de sufragistas, mas uma instituição que se propõe ao progresso intelectual e coletivo da mulher. Depois de várias reuniões preliminares, realizou-se sábado passado a última aprovação definitiva dos estatutos, [...]. Essa assembleia reuniu-se na Escola Orsina da Fonseca, que será um dos órgãos da [...] associação, com a assistência do Dr. Gastão de Azambuja, representando o senador Pinheiro Machado (O Paiz, 05 jun. 1914, p. 4).

Essa tentativa de refundar o partido parece ter sido uma estratégia perpetrada pelos membros do PRF para desvincular a sua imagem à das suffragettes inglesas, tal como se pode observar no excerto acima. Contudo se esse foi o objetivo do grupo, não foi alcançado, uma vez que em 1919, ainda se encontra, na imprensa, a denominação Mrs. Pankhurst brasileira para fazer referência à Daltro. Com efeito, tal vinculação pode ter mais prejudicado que ajudado na campanha do PRF. Porém tudo leva a crer que foi devido à militância de Daltro e do seu inusitado partido que o tema do voto feminino voltou à agenda da imprensa e do Parlamento. Em 1917, Leolinda chegou a ser "homenageada" pelos carnavalescos responsáveis pelo Carnaval de rua do Rio de Janeiro. Os três clubes que desfilaram pelas avenidas da capital federal - os Democráticos, os Tenentes do Diabo e os Fenianos -, fizeram alguma referência ou ao sufrágio feminino ou à pessoa de Leolinda durante seus desfiles. Referências jocosas, mas que demonstram que o mote do sufrágio feminino estava em alta na época. O Fenianos, por exemplo, apresentou no seu desfile um carro denominado "O Voto Feminino", que fazia "uma espirituosa alusão à conhecida professora, useira e veseira $[\mathrm{sic}]$ na catequese dos bororós, que, pela boca de um endiabrado rapaz, procura fazer valer os direitos das saias" (A Época, 21 fev. 1917, p. 5). Também os Democráticos levaram um "carro crítica", intitulado "Professora D'Altro lá com ela", que era assim descrito pelo próprio grupo: 
Não a conhecem? Ora, não há quem desconheça o feminino tipo criticado. Seu nome é barulhento e, por isso mesmo, da berlinda não sai. Quando sucede que nos poucos dias de uma semana não fale na professora d'altro lá com ela, é contar como certo que, no oitavo dia, vai aparecer um pratinho de sensação (O Paiz, 20 fev. 1917, p. 8).

A inspiração para o uso do sufrágio feminino como tema, pelos carnavalescos de 1917, pode ter sido influenciada pelo fato de, no ano anterior, o nome de Daltro foi bastante difundido na imprensa, em um momento em que o PRF já se encontrava estruturado, contando com um novo jornal para ser o divulgador das ideias do partido - A Tribuna Feminina. A plataforma defendida pelo partido em 1916 se mostrava muito ampla, tal como se pode constatar numa matéria publicada no jornal A Noite, que colocou em evidência as diferenças entre o PRF e a recém fundada, na capital federal, Associação da Mulher Brasileira, um grupo filantrópico e de cooperativismo feminino. Segundo a matéria, o PRF, além da busca pelo voto, vinha se dedicando desde a sua fundação a: fundar fábricas, oficinas e ateliês; manter um centro profissional de empregadas domésticas; fundar farmácias; organizar uma exposição de produtos enviados pelos diversos estabelecimentos agrícolas e fabris fundadas e mantidas pela instituição em todo o território nacional; instalar restaurantes e cooperativas vegetarianas, considerada como alimentação higiênica, elementos que o Partido Republicano Feminino reivindicava a primazia através das páginas do jornal (A Noite, 17 set. 1916). Apesar da amplitude de frentes abertas pelo PRF, a questão do voto não foi esquecida e a aproximação das suas partidárias com os políticos também deve ser lembrada como um fator que pode ter resultado que uma primeira tentativa de se estender o voto para as brasileiras tenha ocorrido em $1917^{6}$.

As "homenagens" à Leolinda destacam dois fatos. O primeiro indica que ela era uma figura conhecida na capital federal e que sua luta estava aparecendo e incomodando. O outro fato a se destacar é que o deputado Mauricio de Lacerda pode ter considerado o momento propício para apresentar uma emenda à nova lei eleitoral em vigor (que apenas modificava o procedimento do alistamento eleitoral vigente até então, passando a exigir a exigir uma prova de renda dos

${ }^{6}$ No ano de 1917 Daltro também tentou se qualificar eleitora no Rio de Janeiro, abrindo um processo na junta eleitoral do $4^{\circ}$ Distrito da capital. 
eleitores) solicitando a inclusão das mulheres no rol dos eleitores do Brasil ${ }^{7}$.

Uma nota publicada no jornal $A$ Noite da cidade do Rio de Janeiro, em 20 de dezembro de 1916, dá a conhecer que o Partido Republicano Feminino (PRF) e o deputado Maurício de Lacerda mantinham contato, uma vez que nessa ocasião Lacerda estava requerendo a publicação, no Diário do Congresso, de uma representação do PRF pedindo ajuda para os funcionários públicos (A Noite, 20 dez. 1916, p.3). Dessa relação pode ter surgido a proposta de Lacerda de se estender o alistamento feminino para as brasileiras, uma vez que essa era uma das propostas do PRF. Outro dado que pode corroborar essa conjectura apareceu publicado em outro periódico da capital federal, o jornal $A$ Epoca, no dia 14 de junho de 1917, na primeira das respostas a uma enquete proposta pelo periódico sobre o alistamento feminino ${ }^{8}$. Nesta, a missivista Lucia de Andrade Costa, ao se pronunciar sobre o tema, proclama que:

tenho a certeza absoluta de que, as minhas patrícias repelirão essa inovação perigosa, que vem abalar os alicerces do lar, infiltrando na família o veneno das paixões políticas. Esse novo perigo que nos ameaça devemos a ação dissolvente da professora Leolinda Daltro, que, ao lado de algumas amigas e do deputado Maurício de Lacerda, tudo tem feito para nos arrancar do pedestal em que vivemos, cercadas de respeito público. (A Epoca, 14 jun. 1917, p. 1, grifo nosso).

\footnotetext{
${ }^{7}$ A proposta de Mauricio de Lacerda era mais ampla que somente o alistamento feminino e também propunha mudança na prova de renda para ser eleitor da República. Após a aprovação de nova lei eleitoral, a de número 3.139 de 2 de agosto de 1916, o deputado fluminense Maurício de Lacerda apresentou para a Câmara, no dia 12 de junho de 1917, uma proposta de alteração da referida lei em dois pontos: o primeiro deles no que dizia respeito à proposta de se estender o alistamento eleitoral para as brasileiras; e o outro sobre mudanças na prova de renda para ser eleitor da República. Nessa época Maurício de Lacerda estava no seu segundo mandato como deputado federal pelo Partido Republicano Fluminense. Lacerda foi relator do primeiro Código do Trabalho, além de ter militado na defesa dos direitos trabalhistas, dos direitos civis da mulher e do direito de greve, prestando assim um importante apoio ao movimento operário do início do século.

${ }^{8}$ O periódico A Epoca deu destaque nas suas edições, a partir de 13 de junho de 1917, para a questão do alistamento feminino proposta por Maurício de Lacerda, com a publicação de uma enquete com a seguinte pergunta "Quererão elas concorrer as urnas?". O jornal aproveitou o ensejo da emenda para perguntar para as "mulheres representativas da cultura feminina no Brasil, a respeito desse direito novo que [...] querem lhe oferecer", de modo que oferecia as páginas do jornal, "comprometendo-se a dar publicidade aos votos e razões das nossas patrícias, pró ou contra as ideias progressistas do projeto Maurício de Lacerda" ( $A$ Epoca, 13 jun. 1917, capa). A enquete proposta pelo jornal foi publicada, em todas as edições, sempre com o título: "A mulher brasileira e o direito de voto".
} 
As palavras grifadas no excerto acima parecem denotar uma relação entre Lacerda e Daltro na questão do sufrágio feminino, e pode ter influenciado a que o deputado apresentasse a referida emenda à lei eleitoral. O que se sabe com certeza é que o mote do sufrágio feminino estava em voga no início do ano de 1917, tanto que o mesmo foi um dos temas apresentados no carnaval da capital federal, como apresentado.

A proposta de emenda à lei eleitoral de Lacerda foi a primeira a ser defendida no Congresso brasileiro desde a Constituinte de 1890-1891, pretendia estender o alistamento eleitoral para as brasileiras maiores de 21 anos, foi todavia considerada inconstitucional pela Comissão de Constituição e Justiça e sumariamente rejeitada (Annaes, 1918, v. III, p.580-595). Tal atitude da comissão parece ter inspirado uma reação por parte do PRF, através de uma passeata de mulheres pelas ruas do Rio de Janeiro, em novembro de 1917, como uma resposta ao repúdio à proposta de Lacerda. Seguindo o exemplo das feministas de outros países as partidárias do PRF foram convocadas para participar de uma nova manifestação pública, na qual cerca de 84 mulheres foram para as ruas protestar (Soihet, 2006, p. 25; Pinto, 2003, p. 19).

Após mais uma tentativa frustrada de conseguir o título eleitoral, em agosto de 1919 (Gazeta de Notícias, 23 ago. 1919, p. 5) Leolinda Daltro lançou sua candidatura ao cargo de intendente municipal pelo $1^{\circ}$ distrito da cidade do Rio de Janeiro. Ela própria avaliou a sua candidatura como "uma inovação e de um primeiro passo no sentido de nossa verdadeira emancipação política" (A Noite, 24 set. 1919, capa). Ela realmente participou da eleição, sem conseguir se eleger (Gazeta de Notícias, 27 out. 1919, p. 3-5). No final daquele mesmo ano, mais uma proposta de alistamento eleitoral feminino foi apresentada, agora pelo senador Justo Chermont, em 17 de dezembro de 1919, sendo assim designada: "São extensivas às mulheres maiores de 21 anos as disposições das leis n. 3.139, de 2 de agosto de 1916, e n. 3.208 de 27 de dezembro de 1916, revogada a legislação em contrário" (Diario, 18 dez. 1919, p. 5437).

\section{Precursora do feminismo pátrio}

Em 1920, surgiu outro grupo feminino organizado na capital federal, a Liga pela Emancipação Intelectual da Mulher - LEIM, fundado por representantes da classe mais alta e intelectualizada do Brasil, sob a 
liderança de Bertha Lutz . Segundo Branca Moreira Alves (1980) o que diferenciava a ação desse grupo do formado pelas partidárias de Daltro era a maneira de fazer as suas reivindicações. Para Teresa Marques, "o estilo de ação política de Leolinda Daltro era peculiar. Invadia espaços exclusivamente masculinos, expunha-se pessoalmente as críticas, sempre buscando chamar a atenção da sociedade para as desigualdades e injustiças" (Marques, 2004, p. 161). Já o grupo que se formou em torno de Lutz procurava expor suas ideias através de pronunciamentos públicos, de cartas enviadas para a imprensa procurando "revestir o seu discurso de um tom moderado" (Soihet, 2006, p. 27).

Essa diferença nas táticas e abordagens dos dois grupos pode ser mais bem compreendida se levarmos em conta a trajetória da vida das duas principais figuras que lideraram o movimento: Lutz e Daltro. Tal como salienta Céli Pinto (2003, p. 14), "o feminismo daquele período esteve intimamente associado a personalidades". Enquanto Leolinda Daltro, uma professora de origem humilde, teve de abrir o seu próprio caminho, Bertha Lutz vinha de uma família bem relacionada nos meandros do poder tendo recebido uma educação esmerada e diferenciada. Ambas, porém, são descritas como mulheres de personalidade forte e mesmo de difícil convivência.

O que pode ter ajudado na rápida inserção de Bertha foi que o círculo social da família Lutz era muito extenso, o que teria proporcionado seu livre acesso a um meio social que lhe seria negado, caso fosse de outra classe. Yolanda Lôbo (2010, p. 21) assim descreve o círculo social de Bertha Lutz: "cientistas, políticos, intelectuais, senhoras da alta sociedade paulistana e carioca, diplomatas, jornalistas correspondentes, operários, comerciários". Branca Alves (1980) salienta bem que esse era o "principal trunfo" da Liga, ou seja, a posição social das suas participantes que, circulando pelo seu meio social, conseguiam expor diretamente a sua causa para os homens de poder.

A partir de 1918, também se percebe uma mudança no pensamento dos legisladores brasileiros sobre a questão do sufrágio feminino. Essa mudança ocorrida em poucos anos pode ser creditada a alguns fatores, dentre eles: o fim da Primeira Guerra Mundial; a aprovação do sufrágio feminino em alguns países e, no caso brasileiro, a manifestação

\footnotetext{
${ }^{9}$ Bertha Lutz nasceu na cidade de São Paulo em 1894; filha de Adolpho Lutz (especialista em medicina tropical) e Amy Fowler (enfermeira inglesa). Diplomou-se em Biologia, pela Universidade de Paris, e, em Direito, pela Universidade do Rio de Janeiro. No ano de 1919, concorreu, com êxito, a uma colocação de secretária no Museu Nacional no Rio de Janeiro, tornando-se a segunda mulher a ocupar um posto no serviço público brasileiro.
} 
favorável de Rui Barbosa a questão da inserção feminina no rol de eleitores do Brasil. Barbosa pronunciou-se pela constitucionalidade do sufrágio feminino durante uma das conferencias, por ele concedida, durante a sua campanha presidencial, quando percorreu o país de março a abril de 1919. Na ocasião ele pedia a intervenção do Estado em favor dos trabalhadores e incorporava em seu programa ideias em voga nas principais nações desenvolvidas e, dentre essas ideias, a do sufrágio feminino (Barbosa, 1983) ${ }^{10}$.

Uma tática empregada por Daltro e suas colaboradoras, no começo da década de 1920, pioneira na época, foi descrita pela imprensa quando da apreciação do projeto Chermont apresentado no Senado Federal. Os jornais procuraram enfatizar o que chamaram de atos "inusitados" para descrever o que ocorreu naquela sessão, o Correio da Manhã (RJ), por exemplo, procurou enfatizar que a

professora Daltro compareceu ao Senado com um batalhão de senhoritas, sobraçando ramalhetes de flores, para prestar uma homenagem ao sr. Lopes Gonçalves, que supunham autor do projeto concedendo o direito de voto as mulheres brasileiras. Sabendo depois que o autor do projeto era o Sr. Justo Chermont, as manifestações mudaram de rumo e cobriram de flores o representante do Pará (03 jun. 1921, p.4).

Este fato também foi noticiado no jornal A Noite, que escolheu narrar sob outro ângulo o ocorrido:

O Senado esteve frio apesar da presença da legião da professora Daltro, nas tribunas nobres daquela casa do Congresso. [...] Nada se votou, por não haver número para essa obrigação. Terminada a sessão, quando o Sr. Justo Chermont se retirava do Senado, foi alvo de uma manifestação de apreço por parte das moças que acompanhavam a sra. Daltro na tenaz campanha que ela move para a aprovação do projeto de autoria daquele senador [...]. As moças, que tomaram toda a escadaria daquela casa do Congresso, ergueram vivas ao senador paraense, pai putativo do projeto, cobrindo-o de pétalas de rosas (A Noite, 02 jun. 1921, p.2).

\footnotetext{
${ }^{10}$ No segundo semestre de 1918 também ocorreu um fato importante que ajudou nessa mudança de consciência, Maria José de Castro Rebello Mendes concorreu com êxito a uma vaga no Itamarati através de concurso público, abrindo as portas para outras mulheres seguirem seus passos e tornando-se a primeira mulher a ingressar no Itamarati através de concurso público. A recusa inicial do Itamarati em aceitar a sua candidatura gerou muita polêmica e foi amplamente difundida pela imprensa. Leolinda Daltro e suas colaboradoras se fizeram presentes no exame oral aberto ao público para manifestar sua solidariedade para com a candidata, tal como relatado por Teresa Marques (2004, p. 162).
} 
O jornal A Gazeta de Noticias deu ênfase ao que considerou "o regalo dos humoristas", ironizando o movimento feminino e o papel de Daltro nele, denominando-o de "ridículo e excessivo". Essa participação feminina, apesar de considerada motivo de riso para a imprensa em geral, inaugurou uma nova "tática de pressão" por parte das feministas. A reunião das mulheres no Plenário fez parte de uma convocação publicada nos jornais pelo PRF: "para assistirem a votação do projeto que torna expressamente extensivo à mulher brasileira o direito de voto, a diretoria do Partido Republicano Feminino pede-nos convidarmos as Sras. a comparecer, à 1 hora da tarde ao edifício do Senado" (Correio da Manhã, 02 jun. 1921, p. 3). O projeto de Chermont recebeu parecer favorável da Comissão de Constituição e Diplomacia do Senado, em 11 de maio de 1921, apontando uma importante vitória para o movimento sufragista, ao considerar que o alistamento eleitoral feminino não era inconstitucional (Annaes, 1922, v. I, p. 404-416).

Depois dessa participação na sessão do Senado Federal, o nome de Daltro quase não foi mais citado na imprensa, até 1927 quando da aprovação do voto regional feminino no Rio Grande do Norte e Daltro foi lembrada como a pioneira do movimento feminista brasileiro, como se percebe nesse excerto:

Lutou a professora Daltro com admirável abnegação pela integração da mulher na sociedade, reivindicando para ela direitos e funções até então só assegurados aos homens. E a essa campanha se entregou de corpo e alma [...] até esmorecer diante de tantas dificuldades e, principalmente devido a idade que lhe ia embaraçando a ação. [...] como todos os precursores, ficou esquecida, no meio em que pregou com fé e coragem, uma época em que tudo era indiferença e hostilidade (A Noite, 03 ago. 1934, p. 1).

Na década de 1930 Daltro permaneceu ativa na luta pela emancipação feminina fazendo parte da Aliança Nacional de Mulheres, agremiação fundada em 1931 pela advogada Natércia da Silveira, bem como sendo candidata nas eleições de 1933 e 1934. O pioneirismo de Leolinda, à frente de um dos primeiros movimentos organizados femininos, foi mal compreendido na época, e ela teve que suportar piadas e zombarias em relação à sua luta. O riso e a zombaria há muito eram utilizados pelos que desejavam descaracterizar a emancipação feminina, tal como aponta Rachel Soihet (2005, p. 592): "a utilização da zombaria, ridicularizandose as mulheres, como freio para os possíveis desequilíbrios de poder entre os sexos constitui-se em algo habitual, perdendo-se na sua longa 
duração". Em 1931, esse fato foi comentado pela própria Leolinda em uma outra entrevista concedida por ela na qual desabafa: "o senhor não sabe quanto fui ridicularizada porque simplesmente, só porque me bati por uma aspiração ainda deslocada no tempo em que levantei o estandarte do Feminismo no Brasil" (A Batalha (RJ), 02 abr. 1931, p. 1). Nessa entrevista, o jornalista assim apresentou Leolinda:

uma das mulheres mais populares do Rio de Janeiro a quem a irreverência ligeira do nosso meio ainda em fase de botocudismo agudo, ainda não fez a merecida justiça. [...] a fundadora do Feminismo no Brasil, a sua grande Precursora, aquela que primeiro o vira com verdadeiros olhos, no seu verdadeiro quadro das possibilidades nacionais. Que diria essa velha fagueira do grande ideal, queimando sempre, apesar mesmo, dos baldes d'água fria que lhe atirara a troça fácil dos que não lhe conhecem a historia [...]

Em 1927, tal fato também foi relembrado pela escritora Rachel Prado, que assim se referiu à Leolinda:

se fossemos escrever a história do feminismo no Brasil, certamente que não esqueceríamos a nossa sufragista, a nossa Pankhurst, que foi a pioneira, a esquecida Sra. Leolinda Daltro, professora, desbravadora das nossas selvas, criadora de escolas profissionais, fundadora da primeira escola de enfermeiras no Brasil, organizadora do primeiro partido republicano feminino! Por ser um tanto exaltada, pobre, velha, enferma, quase ninguém a nomeia. Está esquecida (Correio da Manhã (RJ), 06 dez. 1927, p. 1).

Leolinda morreu em 4 de maio de 1935, aos 75 anos de idade, vítima de um atropelamento em uma das mais movimentadas ruas do Rio de Janeiro, na avenida XV de Novembro. No ano anterior, ainda tentou eleger-se, sem sucesso, para uma vaga no Parlamento e, em sua candidatura, reiterou que "a sua campanha feminista precedeu a de todas as senhoras que se apresentam como líderes do feminismo. Foi quem levantou, de longa data, no Brasil, a ideia do direito político da Mulher" (Panfleto de campanha, Fundo FBPF, AP 46, Cx. 16).

\section{Á guisa de uma conclusão}

O papel de Leolinda Daltro nessa primeira fase do movimento organizado sufragista deve ser destacado, uma vez que ela foi uma das mais citadas e lembradas tanto pelos parlamentares quanto pela 
imprensa quando se falava na questão do sufrágio feminino durante a década de 1910 e, parte da década, de 1920. Suas atitudes de confronto e suas tentativas de participar ativamente do mundo político, apesar de mal sucedidas, atraíram a atenção do público para a causa feminista e trouxe visibilidade para o tema. Por seu pioneirismo sofreu com o preconceito e a incompreensão.

Apesar de todas as suas lutas e posicionamentos, Leolinda não procurou revolucionar o papel da mulher na sociedade, mas, sim reformar o papel dela, integrá-la de forma mais justa e igualitária na sociedade brasileira e, através da educação, buscou dar oportunidades para as mulheres integrarem-se à vida pública. Mais do que uma revolução nos costumes, ela procurou reformar as leis para que a brasileira pudesse atuar de forma equivalente à dos homens, com as mesmas oportunidades e direitos. E assim devemos entender o seu pioneirismo no que seus filhos acharam por bem nomear de "feminismo pátrio". O seu papel na história brasileira merece ser conhecido e reconhecido.

\section{Referências}

ABREU, Maria Emilia Vieira de. Professora Leolinda Daltro: Uma proposta de catequese laica para os indígenas do Brasil: 1895-1911. 2007. 101 f. Dissertação (Mestrado em Educação) - Pontifícia Universidade Católica de São Paulo.

ABREU, Maria Zina Gonçalves de. Luta das Mulheres pelo Direito de Voto. Movimentos sufragistas na Grã-Bretanha e nos Estados Unidos. Arquipélago - Revista da Universidade dos Açores, Ponto Delgada, 2ª série, VI, 2002.

ANNAES da Câmara dos Deputados. Sessões de 2 a 31 de julho de 1917. Rio de Janeiro: Imprensa Nacional, 1918. Vol. III.

ANNAES do Senado Federal. Sessões de 18 de abril a 31 de maio de 1921. Rio de Janeiro: Imprensa Nacional, 1922. Vol. I.

ALVES, Branca Moreira. Ideologia e feminismo. A luta da mulher pelo voto no Brasil. Petrópolis: Vozes, 1980.

BARBOSA, Rui. A questão social e política no Brasil. Rio de Janeiro: Fundação Casa de Rui Barbosa, 1983.

BOLETIM ELEITORAL, Estados Unidos do Brasil, ano III, Rio de Janeiro, 13 de junho de 1934.

COELHO, Mariana. A evolução do feminismo. Subsídios para a sua história. 2. ed. Curitiba: Imprensa Oficial do Paraná, 2002.

DIÁRIO DO CONGRESSO NACIONAL. 18 de dezembro de 1919.

DIÁRIO OFICIAL. 17 de dezembro de 1910.

FUNDO da Federação Brasileira pelo Progresso Feminino. Consultado no Arquivo Nacional, Rio de Janeiro. 
GINZBURG, Carlo. Mitos, emblemas, sinais: morfologia e história. 2. ed. São Paulo: Companhia das Letras, 2007.

HAHNER, June E. Emancipação do Sexo Feminino. A luta pelos direitos da mulher no Brasil, 1850-1940. Florianópolis: Ed. Mulheres; Santa Cruz: EDUNISC, 2003.

LOBO, Yolanda. Bertha Lutz. Recife: Fundação Joaquim Nabuco, Editora Massangana, 2010.

MARQUES, Teresa Cristina de Novaes. Elas também desejam participar da vida pública: várias formas de participação política feminina entre 1850 e 1932. Gênero, Niterói, v. 4, n. 2, p. 149-169, 1 sem. 2004.

MELO, Hilda Pereira de; MARQUES, Teresa Novaes. Partido Republicano Feminino - A construção da cidadania feminina no Rio de Janeiro. Revista do Instituto Histórico e Geográfico do Rio de Janeiro, Rio de Janeiro, 2000.

PERROT, Michelle. As mulheres ou os silêncios da história. Bauru: EDUSC, 2005.

PINTO, Céli Regina Jardim. Uma história do feminismo no Brasil. São Paulo: Fundação Perseu Abramo, 2003.

PUGH, Martin. The March of the Women. A revisionist analysis of the campaign for women's suffrage, 1866-1914. London: Oxford University Press, 1999.

ROCHA, Elaine Pereira. Entre a pena e a espada: a trajetória de Leolinda Daltro (1859 - 1935) - patriotismo, indigenismo e feminismo. 2002. 335 f. Tese (Doutorado em História) - Universidade de São Paulo, São Paulo.

ROWBOTHAM, Sheila. A Century of Women. The History of Women in Britain and the United States. London: Viking, 1997.

SCHUMAHER, Shuma, BRAZIL, Érico Vital (Org.). Dicionário Mulheres do Brasil: de 1500 até a atualidade. Rio de Janeiro: Jorge Zahar Ed., 2000.

SCOTT, Joan W. Género e historia. México: FCE, Universidad Autónoma de la Ciudad de México, 2008.

SCOTT, Joan Wallach. A cidadã paradoxal. As feministas francesas e os direitos do homem. Florianópolis: Ed. Mulheres, 2002.

SOIHET, Rachel. Zombaria como arma antifeminista: instrumento conservador entre libertários. In: Estudos Feministas, Florianópolis, v. 13, n. 3, p. 591-611, set.-dez. 2005.

SOIHET, Rachel. O feminismo tático de Bertha Lutz. Florianópolis: Ed. Mulheres; Santa Cruz do Sul: EDUNISC, 2006.

SOUZA, Esmeraldino. Bertha Lutz na visão de um técnico aprendiz. História, Ciências, Saúde - Manguinhos, Rio de Janeiro, v. 10, n. 1, p. 413-419, jan.-abr. 2003.

STRANSELL, Christine. The feminist promise: 1792 to the present. New York: Modern Library, 2010.

VERJUS, Anne. Voto familiarista e voto familiar. Contribuição para o estudo do processo de individualização das mulheres na primeira metade do século XIX. In: CANEDO, Letícia Bicalho (Org.). O sufrágio universal e a invenção democrática. São Paulo: Estação Liberdade, 2005. 